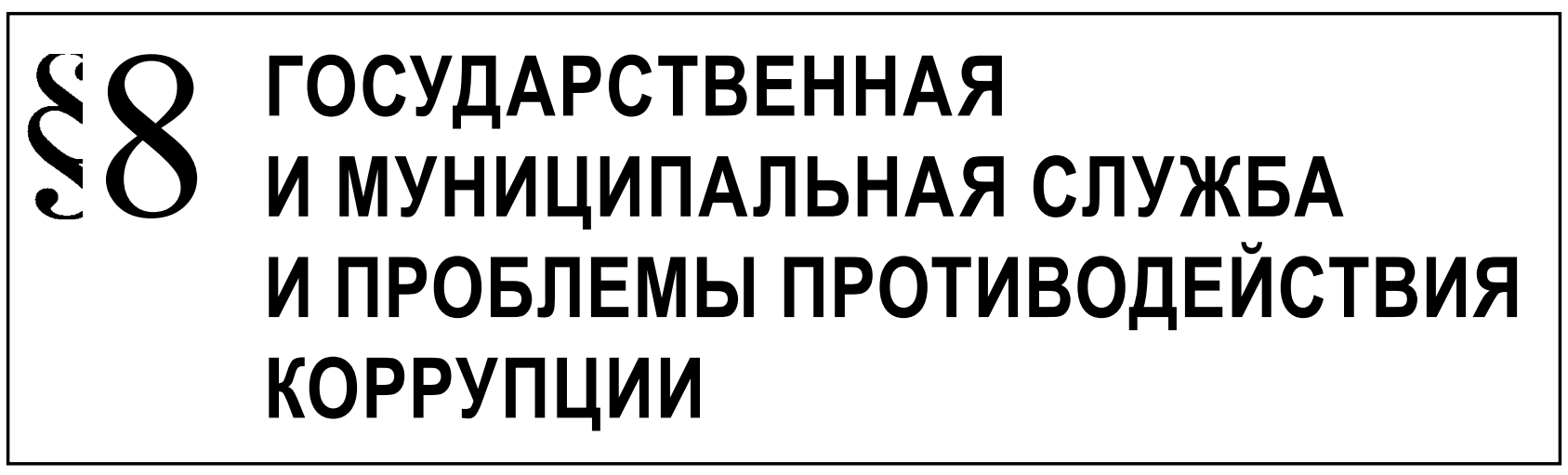

Красноусов С.Д.

\title{
К ВОПРОСУ О ФОРМИРОВАНИЯ В ЦЕЛЯХ ПРОТИВОДЕЙСТВИЯ КОРРУПЦИИ СИСТЕМЫ ЗАПРЕТОВ, ОГРАНИЧЕНИЙ И ОБЯЗАННОСТЕЙ
}

Аннотация: Согласно Указу Президента РФ от 11.04.2014 N 226 "О Национальном плане противодействия коррупции на 2014 - 2015 годы" определены актуальные на 2014-2015 г.г. темы для научных исследований. Одной из них является тема - формирование в целях противодействия коррупции системы запретов, ограничений и обязанностей, в том числе в отношении коммерческих организаций. В данной статье с точки зрения теории мер безопасности рассматриваются антикоррупционные ограничения в отношении бывшего сотрудника коммерческой организации, перешедшего работать в орган власти. При проведении исследования применялись общенаучные и специальные методы познания: анализ, синтез, моделирование, формально-логический, системно-структурный, социологический и статистический методы. Согласно действующему законодательству может возникнуть ситуация, когда лицо - управляющий коммерческой или иной организацией, которая была замечена в использовании коррупционных отношений (сама организация либо сотрудники такой организации привлечены к ответственности за коррупционные правонарушения), может без каких либо ограничений поступить на руководящую должность в государственный или муниципальный орган.Представляется, что поступление на службу не изменяет отношение лица к своему поведению и правилам управления. В таком случае государство, как наниматель при наличии информации о том, что поступающий на службу субъект проявил себя как недобросовестный управляющий, который совершал противоправные действия , был нечестным и не выполнял со всей тщательностью и аккуратностью своих обязанностей, должно иметь гарантии не совершения данным лицом подобных действий и на государственной службе. В настоящий момент для целей предотвращения поступления на службу недобросовестного лица, использующего коррупционные отношения, можно использовать институт ответственности управляющего за действия организации.Предлагается дополнить Закон о противодействии коррупции статьей 12.6 «Ограничения, налагаемые при переходе на государственную или муниципальную службы гражданина, выполнявшего управленческие функции в коммерческой или некоммерческой организации, которая была привлечена кответственности за совершение коррупционных правонарушений (сотрудники которой были привлечены за коррупционные правонарушения)».

Ключевые слова: предупреждение в организациях, о противодействии коррупции, управляющий организации, государственная служба, муниципальная служба, меры безопасности, система органичений, указ президента 2014-2015, частный сектор, ответственность руководителя организации.

огласно Указу Президента РФ от 11.04.2014 N 226 «О Национальном плане противодействия коррупции на 2014 - 2015 годы» ${ }^{1}$ опре-

1 Указ Президента РФ от 11.04.2014 N 226 «О Национальном делены актуальные на 2014-2015 г.г. темы для научных исследований. Одной из них является тема ормирование в целях противодействия коррупции

плане противодействия коррупции на 2014 - 2015 годы» 
системы запретов, ограничений и обязанностей, в том числе в отношении коммерческих организаций.

В настоящее время согласно статье 12 Закона о противодействии коррупции ${ }^{2}$, при заключении трудового договора на лицо, ранее замещавшем должность на государственной или муниципальной службе, налагаются ограничения при последующем трудоустройстве.

Согласно действующему законодательству может возникнуть следующая ситуация: лицо - управляющий коммерческой или иной организацией, которая была замечена в использовании коррупционных отношений ${ }^{3}$ (сама организация либо сотрудники такой организации привлечены к ответственности за коррупционные правонарушения), может без каких либо ограничений поступить на руководящую должность в государственный или муниципальный орган.

Подобная ситуация, на наш взгляд, способствует подрыву авторитета власти и формированию негативного образа служащего. Законодательство о прохождении государственной службы требует от служащего ${ }^{4}$ исполнять должностные обязанности добросовестно. Лексический смысл добросовестности - честный, выполняющий свои обязательства ${ }^{5}$. «В праве добропорядочным может быть признано такое поведение субъекта, которое не противоречит предписаниям правовых норм, признается полезным, нужным... Добросовестность следует понимать как честное, со всей тщательностью и аккуратностью выполнение обязанностей, старательность, исполнительность» ${ }^{6}$. С.А. Иванова

\footnotetext{
2 Федеральный закон от 25.12.2008 №273-Ф3 «О противодействии коррупции» // Российская газета. - 2008. 30 дек. (№ 4823),

3 Уточним, что в данном случае мы говорим о том, что само лицо не привлекалось к уголовной ответственности, но руководило организацией.

4 См. подпункт 2 пункта 1 статьи 18 Федеральный закон от 27.07.2004 N 79-Ф3 «О государственной гражданской службе Российской Федерации». Федеральный закон от 02.03.2007 N 25-Ф3 «О муниципальной службе в Российской Федерации» не содержит требования о добросовестности служащего. Представляется, что руководствуясь принципом проведения единой государственной политики в области противодействия коррупции, заложенным в Федеральном законе от 25.12.2008 N 273-Ф3 «О противодействии коррупции» законодатель в дальнейшем исправит данное рассогласование в актах о службе.

5 Толковый словарь русского языка / Под ред. С.И. Ожегова и Н.Ю. Шведовой. М., 1997. С. 169.

6 Бабаев В.Н. Презумпции в советском праве. Горький, 1974. C. 87.
}

конкретизирует, что под понятиями «добросовестность» и «недобросовестность» следует понимать проявляемое в процессе совершения действий психическое отношение лица к предвидимому вреду или к возможности его предвидения, имеющейся у среднего вменяемого (разумного) человека7.

Представляется, что поступление на службу не изменяет отношение лица к своему поведению и правилам управления. В таком случае государство, как наниматель при наличии информации о том, что поступающий на службу субъект проявил себя как недобросовестный управляющий, который совершал противоправные действия ${ }^{8}$, был нечестным и не выполнял со всей тщательностью и аккуратностью своих обязанностей, должно иметь гарантии не совершения данным лицом подобных действий и на государственной службе.

В настоящий момент для целей предотвращения поступления на службу недобросовестного лица, использующего коррупционные отношения, можно использовать институт ответственности управляющего за действия организации.

Для дальнейшего рассмотрения вопроса, необходимо определить каким образом будет устанавливаться ответственность лица за коррупционные действия своей организации.

Представляется, что данная норма об особом порядке приема на службу может быть установлена только для руководителей юридических лиц, т.е. лиц от которых зависит принятие решений о развитии данной организации и которые в силу этого в целом отвечают за управления в организации. Иные субъекты не обладают полнотой информации для принятия соответствующих решений, а общественная опасность от их действий, если они не совершают преступления, значительно меньше, чем у руководителей.

На наш взгляд оба этих карьерных перемещения должны являться основанием к проведению специальной процедуры принятия на работу:

\footnotetext{
Иванова С.А. Некоторые проблемы реализации принципа социальной справедливости, разумности и добросовестности в обязательственном праве // Законодательство и экономика. 2005. N 4.

8 Мы не рассматриваем ситуацию совершения лицом преступления, так как сам факт осуждения его к наказанию, исключающему возможность исполнения должностных обязанностей по должности государственной службы по приговору суда, вступившему в законную силу, а также наличие не снятой или не погашенной судимости является препятствием к его принятию на гражданскую службу.
} 
во-первых, законодатель при конструировании данной нормы хотел избежать возможности легализовать полученное на государственной или муниципальной службе незаконное вознаграждение, полученное в результате незаконного использования ресурсов государственной и муниципальной службы лицом в независимости от того каким образом оно используется;

во-вторых, общественная опасность такого перемещения равнозначна: в первом случае (службаорганизация) - лицо может использовать свои связи в интересах бывшей управляемой организации; во втором (организация-служба) - он, уже понимая интересы управляющей организации, сможет обеспечить их в рамках своей службы;

в-третьих, в первом случае мы будем иметь место использование своих связей, а во втором - может быть злоупотребление полномочиями, дача/ получение взятки и т.д., т.е. совершение преступления и это, на наш взгляд, увеличивает степень общественной опасности последствий отказа от таких ограничений;

в-четвертых, данная норма будет являться стимулом для руководителей организации принимать и реализовывать антикоррупционные программы, чтобы обезопасить себя.

Руководствуясь вышесказанным, предлагаем дополнить Закон о противодействии коррупции статьей 12.6 «Ограничения, налагаемые при переходе на государственную или муниципальную службы гражданина, выполняющего управленческие функции в коммерческой или некоммерческой организации ${ }^{9}$, которая была привлечена к ответственности за совершение коррупционных правонарушений (сотрудники которой были привлечены за коррупционные правонарушения)» в следующей редакции:

Гражданин, выполняющий управленческие функции в коммерческой или некоммерческой организации, которая была привлечена к ответственности за совершение коррупционных правонарушений (сотрудники которой были привлечены за коррупционные правонарушения), в течение двух лет после увольнения имеет право замещать должности государственной или му-

\footnotetext{
9 Мы сознательно уходим от разграничения таких организаций на оказывающие публичные услуги, естественные монополии, градообразующие предприятия моногородов и др. так как оно не имеет принципиального значения в контексте этой статьи и лишь усложнит конструкцию нормы.
}

ниципальной службы, перечень которых устанавливается нормативными правовыми актами РФ, если отдельные функции государственного управления данными организациями будут входить в его должностные (служебные) обязанности, с согласия соответствующей комиссии по соблюдению требований к служебному поведению государственных гражданских служащих РФ и урегулированию конфликта интересов, которое дается в порядке, устанавливаемом нормативными правовыми актами РФ;

Гражданин, выполнявший управленческие функции в коммерческой или некоммерческой организации, при поступлении на службу в орган, указанный в части 1 настоящей статьи в течение двух лет после увольнения обязан при заключении трудовых договоров сообщать представителю нанимателя (работодателю) сведения об организации, которая была привлечена к ответственности за совершение коррупционных правонарушений (сотрудники которой были привлечены за коррупционные правонарушения) при выполнении им управленческих функций.

Несоблюдение гражданином, условий, предусмотренных частями 1,2 настоящей статьи, влечет его увольнение с государственной или муниципальной службы;

Наниматель (работодатель) при приеме на службу гражданина, указанного в части 1 настоящей статьи, обязан в десятидневный срок сообщать о таком приеме в комиссию по соблюдению требований к служебному поведению Российской Федерации и урегулированию конфликта интересов в порядке, устанавливаемом нормативными правовыми актами Российской Федерации;

Неисполнение нанимателем (работодателем) обязанности, установленной частью 4 настоящей статьи, является правонарушением и влечет ответственность в соответствии с законодательством Российской Федерации.

Указанные выше предложения являются логичным завершением работы по совершенствованию положений Закона о противодействии коррупции с учетом рекомендаций международных актов, в том числе Конвенции ООН против коррупции, и не требуют дополнительного обоснования их введения. Внесение таких изменений обосновывается значимостью системного подхода в противодействии коррупции. Нами не предлагаются новые меры, так как мы полагаем, что на первоначальном этапе, при низкой активности использования не принудительных мер противодействия рано 
Административное и муниципальное право 1 (85) • 2015

говорить о расширении перечня мер безопасности $^{10}$. Такое расширение, на наш взгляд, возможно только при осознании не только государством, но и обществом, а также профессиональным сообществом опасности коррупции внутри организаций и между ними.

\section{Библиография:}

1. Указ Президента РФ от 11.04.2014 N 226 "О Национальном плане противодействия коррупции на $2014-2015$ годы"

2. Федеральный закон от 25.12.2008 №273-Ф3 «0 противодействии коррупции» // Российская газета. - 2008. 30 дек. (№ 4823).

3. И.А.Зырянова, Н.В.Хлонова, Н.В.Щедрин Концептуально-теоретические основы правового регулирования и применения мер безопасности : монография / под науч. ред. Н. В. Щедрина; Сиб. федер. ун-т. Красноярск: СФУ, 2010. С. 242.

4. Федеральный закон от 27.07.2004 79-Ф3 «О государственной гражданской службе Российской Федерации» // Российская газета. - 2004.- 31 июля. (№ 162).

5. Федеральный закон от 02.03.2007 N 25-Ф3 «0 муниципальной службе в Российской Федерации»

6. Толковый словарь русского языка / Под ред. С.И. Ожегова и Н.Ю. Швведовой. М., 1997. С. 169.

7. Бабаев В.Н. Презумпции в советском праве. Горький, 1974. С. 87.

8. Иванова С.А. Некоторые проблемы реализации принципа социальной справедливости, разумности и добросовестности в обязательственном праве // Законодательство и экономика. 2005. N 4

\section{References (transliterated):}

1. Ukaz Prezidenta RF ot 11.04.2014 N 226 "O Natsional'nom plane protivodeistviya korruptsii na 2014-2015 gody"

2. Federal'nyi zakon ot 25.12.2008 №273-FZ «O protivodeistvii korruptsii»// Rossiiskaya gazeta. - 2008 . 30 dek. (№ 4823).

3. I.A.Zyryanova, N.V.Khlonova, N.V.Shchedrin Kontseptual'no-teoreticheskie osnovy pravovogo regulirovaniya i primeneniya mer bezopasnosti : monografiya / pod nauch. red. N. V. Shchedrina; Sib. feder. un-t. Krasnoyarsk: SFU, 2010. S. 242.

4. Federal'nyi zakon ot 27.07.2004 79-FZ «O gosudarstvennoi grazhdanskoi sluzhbe Rossiiskoi Federatsii» // Rossiiskaya gazeta. - 2004.- 31 iyulya. (№ 162).

5. Federal'nyi zakon ot 02.03.2007 N 25-FZ «0 munitsipal'noi sluzhbe v Rossiiskoi Federatsii»

6. Tolkovyi slovar' russkogo yazyka / Pod red. S.I. Ozhegova i N.Yu. Shvvedovoi. M., 1997. S. 169.

7. Babaev V.N. Prezumptsii v sovetskom prave. Gor'kii, 1974. S. 87.

8. Ivanova S.A. Nekotorye problemy realizatsii printsipa sotsial'noi spravedlivosti, razumnosti i dobrosovestnosti v obyazatel'stvennom prave // Zakonodatel'stvo i ekonomika. 2005. N 4

\footnotetext{
10 В трактовке мер безопасности мы опираемся на разработки И.А. Зыряновой, Н.В. Хлоновой и Н.В.Щедрина, по их мнению, в общем виде «антикоррупционные меры безопасности можно определить как меры принудительного ограничения поведения субъектов коррупции, применяемые при наличии указанных в законе оснований и имеющие целью защиту общественных отношений от вредоносных коррупционных посягательств. Их непосредственной целью является защита общественных отношений в различных сферах жизнедеятельности общества от опасности возникновения и распространения коррупции». См.: Н.В.Щедрин Концептуально-теоретические основы правового регулирования и применения мер безопасности : монография / под науч. ред. Н. В. Щедрина; Сиб. федер. ун-т. Красноярск: СФУ, 2010. С. 163.
} 